\title{
Ved Niels Heldvads skrivepult
}

Et bidrag til en litterær analyse

\author{
Af Urban Schroder.
}

Efter at præsten i Hellevad og Egvad Niels Heldvad - en af de betydeligste og interessanteste skikkelser indenfor vor landsdels kirkehistorie - i julen 1611 for anden gang havde måttet forlade sogn og hjem og med sin husstand var draget fra gottorpsk til kongeligt område, fik han fra 1613 i nogle år sit foreløbige opholdssted i Svendborg, hvor adelsmanden Jacob Rosenkrantz til Arreskov og Kærstrup forundte ham og hans familie bolig i det tidligere gråbrødrekloster. ${ }^{1}$ Senere gik hans vej som bekendt til København, hvor han også til sidst fandt sin grav.

Men selvom han altså siden 1611 ikke mere virkede på slesvigsk grund, og selvom en række af hans betydeligste bøger herefter blev udgivet i København, ${ }^{2}$ kan vi dog ikke betragte ham som en mand, der efter nævnte år ikke mere vedkommer slesvigsk historie. Indtil sin sidste stund følte han sig som slesviger, omend han af forholdene var blevet tvunget til at leve udenfor sit snævrere fædreland. F. ex. hører vi ham i fortalen til sit skrift »TRIFOLIUM Theologicum " $1628,{ }^{3}$ der er dediceret de to præstesønner fra Udbjerg, ridefogederne Jens og Anders Andersen i Halland og Halmstad, ${ }^{4}$ sige, at han skænker dem dette skrift bl. a. "til en bestandig hukommelse, at vi have været og endnu ere gode venner og landsmænd tilsammen og langt adskilt fra vores fædreneland «. ${ }^{5} \mathrm{Og}$ så sent som på Sct. Laurentius' dag 1634 - knap 14 dage før sin død - slutter han fortalen til sit sidste skrift "HISTORIARUM SACRARUM ENCOLPODION $\otimes^{8}$ med at underskrive sig "Nicolaus Heldvaderus, Jesu Christi Servus et Exul " Jesu Kristi tjener og flygtning. ${ }^{7}$ Begge steder taler den fordrevne slesviger, der aldrig kunde glemme sin hjemstavn. Vi tillader os derfor at betragte Niels Heldvad som en mand, der også efter sin 
fordrivelse fra landet Slesvig vedkommer dettes historie, og hvis skrifter også efter 1611 kan bidrage til at kaste lys over slesvigske forhold.

Dette sidste gælder således den fint trykte og smukt illustrerede opbyggelsesbog, som han lod trykke hos Henrick Waldkirch $i$ København 1616 under titelen:

\title{
CORONULA ROSEA \\ HELDWADERI:
}

\author{
Det er 1 \\ Alle Bedraffue- \\ de Hierters oc Bodferdi- \\ ge Synderes Rosenkrantz / nyligen \\ aff HErrens Paradiss colligeret oc til- \\ sammendraget / til at Ziere / fryde oc krone alle \\ dennem / som vnder atskillige nod / Kaars / oc \\ modgang riderlig holde sig / oc for det E- \\ vigt oc Wforgengeligt Mandeligt \\ Kempe oc stride.
}

I dette skrift, hvis tilegnelse er stilet til Niels Heldvads velgører Jacob Rosenkrantz' hustru Petronelle Gyldenstjerne og parrets 8 døtre, og som sikkert er blevet til under opholdet i Svendborg, findes til slut et afsnit med overskriften »En skøn / nyttig Vndervisning oc Christelig paamindelse/ huorledis Mand ordentlig oc retteligen kand bruge Davids Psalter«(Bl. Pff). Her finder vi en grundig anvisning på en planmæssig brug af Kirkens ældste bønnebog, kong Davids Psalmer i Det gamle Testamente. Niels Heldvad opregner, hvilke psalmer der kan "læses ${ }^{10}$ på kirkeårets festdage - herunder også "på de 3 Vor Frue højtider ", Kyndelmisse dag 2. febr., Mariæ bebudelses dag 25. marts og Mariæ bjergegangs eller besøgelses dag 2 . juli, der dengang og længe efter ligesom Sct. Hans' dag 24. juni og Mikkels dag 29. sept. endnu fejredes blandt kirkeårets helligdage (Pf). Han anforer Davidspsalmer til hver årets søndag »i koret og på orgelværk, item til ugeprædiken, at de komme overens med evangelio" (Pvff). Han glemmer ikke årets 12 aposteldage, men nævner også psalmer til hver af dem (P2v). Og han anfører, shvorledes man kan bruge Psalteren hver efter sin stand og lejlighed (P3ff), og hvilke psalmer der egner sig "for alle retsindige kristne " under livets skiftende forhold (P4ff). 
Det er om dette afsnit i »CORONULA ROSEA ", at H. V. Gregersen $i$ sin bog om Niels Heldvad har fremsat den interessante hypotese, at vi her står overfor et materiale fra de tidebønner og andre hverdagsgudstjenester, som Niels Heldvad sandsynligvis som tjenstledig præst har forestået i gråbrødreklosteret i Svendborg og i kirken i det tidligere Holmekloster, det nuværende Brahetrolleborg på Sydfyn, hvor han i disse år også af og til opholdt sig hos rigsråden Breide Rantzau. ${ }^{11}$ Men det er også til denne hypotese, der her skal knyttes nogle korrigerende bemærkninger, som forer os fra kongeriget tilbage på slesvigsk grund.

Det er rigtigt, at de i middelalderen almindelige tidebønner $i$ vore kirker og klostre ikke blev afskaffede med reformationen, men levede videre indenfor vor reformerede kirke længe efter kirkebruddet i 1500-årene. Således bragte både den kongerigske kirkeordinans $1539 \mathrm{og}$ kirkeordningen for hertugdømmerne 1542 udførlige forskrifter for de daglige tidebønner, som skulle fejres af latinskoleeleverne og kannikerne i kirker og klostre. ${ }^{12} \mathrm{Og}$ først engang i 1700-årene forstummede den ældgamle katolske tidesang i vor kirke og afløstes helt af hverdagsgudstjenester af et andet præg, væsentligt bestående af prædiken og almindelig salmesang. ${ }^{23}$

For så vidt har Gregersen ret $i$, at Niels Heldvad kan have medvirket ved tidebønnerne både $\mathrm{i}$ Svendborg og på Brahetrolleborg. ${ }^{14}$ Og hans *Vndervisning * om brugen af Davids psalmer, der udgjorde hovedbestanddelen af tidebønnerne, kan afspejle noget af hans virksomhed her. Men at han selv skulle have udarbejdet denne anvisning for psalmernes brug, at den skulle være så at sige hans egen tidebønneplan - det er det, som vi i det følgende skal påvise ikke kan være tilfældet.

For det første er tidebønnerne som bekendt hovedsageligt et hverdagsfænomen, selvom naturligvis også søn- og helligdagene har disse bønner med deres eget præg. Sådan har den kirkelige tradition været siden de ældste tider. ${ }^{15}$ Men Niels Heldvads anvisning bringer jo ingen Davidspsalmer til brug på hverdagene. Han anfører som allerede nævnt psalmer, der kan bruges på kirkeårets søndage og særlige festdage, samt psalmer, som enhver kan bede efter sin stand og lejlighed. Den eneste antydning af, at han også kan have tænkt på psalmer til hverdagsbrug, er de her fremhævede ord $\mathbf{i}$ følgende overskrift: "Til at bruge psalmerne på søndagene $i$ 


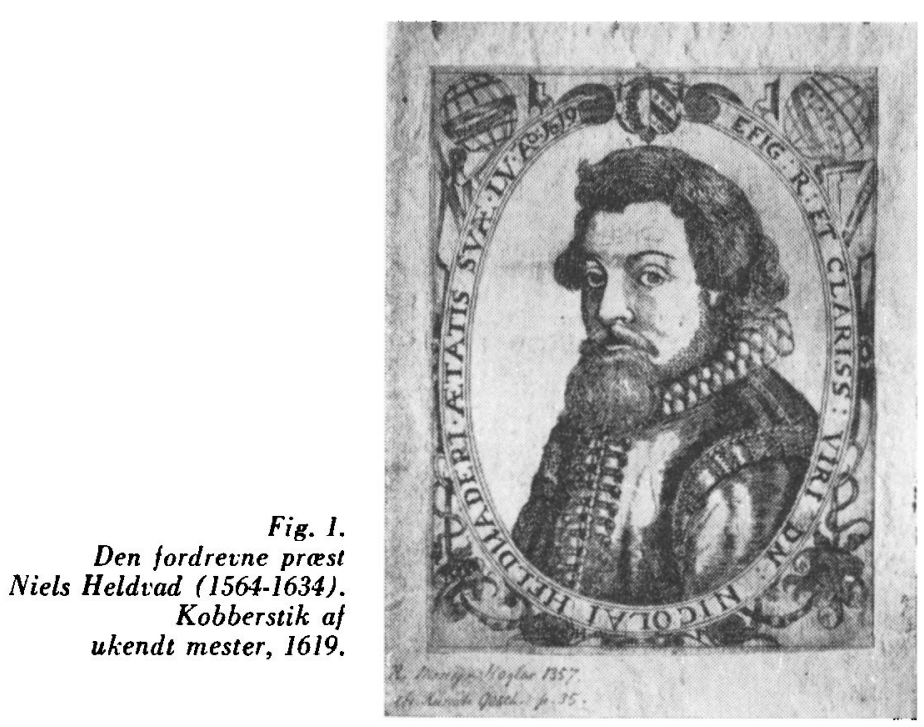

koret og på orgelværk, item til ugepradiken, at de komme overens med evangelio « (Pv). Men læser vi de derpå følgende sider, finder vi kun psalmer til søndagene og ingen til de pä visse hverdage holdte prædikegudstjenester. ${ }^{16} \mathrm{Og}$ at hans følgende fortegnelse over psalmer for »hver efter sin stand og lejlighed "(P3ff) skulle kunne tydes som en anvisning for egentlige tidebønner på hverdagene, er ikke sandsynligt, da indholdet her netop peger direkte hen på enhvers lejlighedsvise behov.

For det andet - og det er her hovedsagen - har en nærmere undersøgelse vist, at Niels Heldvads anvisning på Davidspsalmernes brug $i$ virkeligheden kun for en meget ringe dels vedkommende er hans eget arbejde. Den er for hovedpartens vedkommende et litterært lån. $O g$ her som mange andre steder $i$ sin litterære produktion er han mere afskriveren og bearbejderen end den virkelige forfatter. Allerede et overfladisk kendskab til hans produktion viser, hvordan han f. ex. flere gange har skrevet af efter sig selv. ${ }^{17}$ Eller han har - hvilket var helt almindeligt i datiden foretaget uddrag af andre mænds bøger og bearbejdet det således fundne stof og omformet det med sin egen pen. ${ }^{18}$ Dette sidste er netop tilfældet med hans »Vndervisning " om Psalterets anvendelse 
kirkeåret igennem. Ja, her har han næsten kun virket som afskriveren. $O g$ hans kilde er her en tysk udgave af Davids psalmer fra begyndelsen af 1600 -årene.

I året 1582 udsendte bogtrykkeren Nicolaus Wegener i Slesvig ${ }^{19}$ en fin, på pergament trykt Psalterudgave med titelen »Der Psalter mit Kurtzen Summarien / vnd einem ordentlichen Register der Psalmen. D. Mart. Luth. «. Det drejer sig her om Luthers oversættelse af psalmerne. Og titelens omtale af et register over disse får os straks til at tænke på Niels Heldvads psalmeregister. En sammenligning viser imidlertid, at det ikke er denne udgave, han har brugt, idet dens tilsidst trykte register — "Ein kurtzes / aber sehr nützliches Register / in welchen Psalmen solche stück sonderlich gehandelt werden " - er ganske kort og kun anfører lære-, trøste-, forjættelses-, takke- og bønspsalmer, der slet ikke har nogen ordning efter kirkeåret. Men der må have existeret flere, nu ikke kendte tyske udgaver af Davids psalmer, som har været brugt her $i$ landet Slesvig. Og det er lykkedes forfatteren af disse sider at finde en sådan senere tysk Psalterudgave, der tilsyneladende er et nyere optryk af Nicolaus Wegeners udgave og meget vel kan have været Niels Heldvads kilde.

Denne senere udgave mangler desværre titelbladet og blad A2 samt de sidste få sider og kan derfor ikke nøjagtigt tids- eller stedfæstes. Men efter sit typografiske udstyr synes den at være trykt et stykke tid ind i 1600-årene; og den er sandsynligvis et slesvigsk arbejde. ${ }^{20}$ Den adskiller sig fra Wegeners udgave dels ved en let sproglig korrigering, ${ }^{21}$ dels - og det er $\mathrm{i}$ vor sammenhæng det særligt interessante - derved, at dens afsluttende register er langt udførligere. Hos Wegener fylder registeret kun $2^{1 / 2}$ side. I vor udgave fylder det 13 sider foruden de nu tabte sidste sider og har til overskrift disse ord: "Folgen vier nützliche Register" (Pvff), mens Wegener kun taler om "ein kurtzes" register. Sammenligner vi nu de to udgaver, ser vi, at af disse fire registre i vor udgave er det første væsentligt identisk med hele Wegeners". Det andet og tredie, som altså ikke findes hos Wegener, er derimod så godt som identiske med Niels Heldvads "Vndervisning" om Psalterets brug. ${ }^{23}$

Dette ser vi straks, når vi lægger de to texter side om side. Hvor vor Psalterudgave har ordene: »Das andere Register. Auf die vor- 


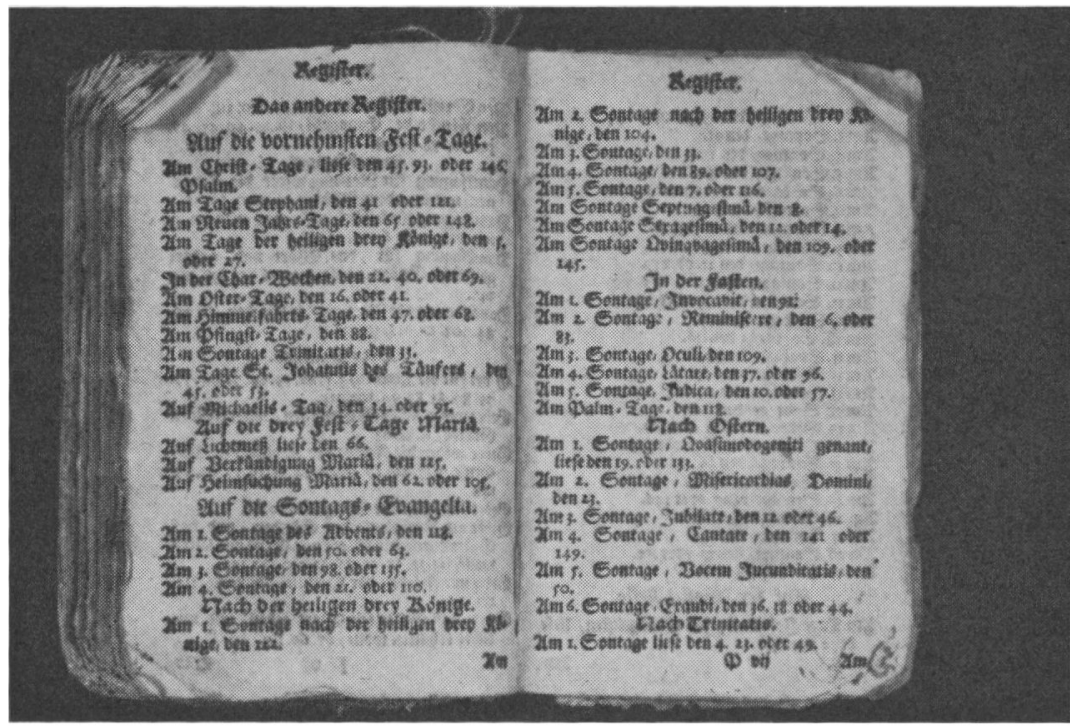

Fig. 2.

Opslag $i$ registeret til den tyske udgave af Davids Psalmer, som Niels Heldvad har brugt. Sammenlign teksten her med teksten pä fig. 3. Foto: H. Ingwersen, Gråsten.

nehmsten Fest-Tage _ - _ Auf die drey Fest-Tage Mariä " (P6v), skriver Niels Heldvad frit gengivende: „Om festdagene skal man læse disse efterfølgende — — - På de 3 Vor Frue højtider" (Pf). Hvor vor tyske udgave opregner psalmerne "Auf die Sonntags-Evangelia « og så nævner kirkeårets perioder fra advents- til trinitatistiden (P6ff), har Niels Heldvad samme kirkeårsrytme: -Til at bruge psalmerne på søndagene - — - advent - - efter hellige tre konger -- udi faste $-\ldots$ imellem påske og pinsehøjtid - - efter trinitatis" (Pvff). Også i hans rubrik "På apostlenes højtider" (P2vf) går vor tyske udgaves "Auf der Apostel Feste (P7vf) igen. Og når han bringer sin anvisning for enhvers individuelle anvendelse af Davids psalmer og skriver: "For det forste ere præstemænds bønner - - - For det andet folger øvrigheds bønner - _ - for det tredie nogle psalmer for alle retsindige kristne (P3ff), så har vi her hele vort tyske Psalters tredie register »Für die, so in Aemtern sind. Als Prediger - Obrigkeit -- - - In gemein für alle Christen « (P8ff). 


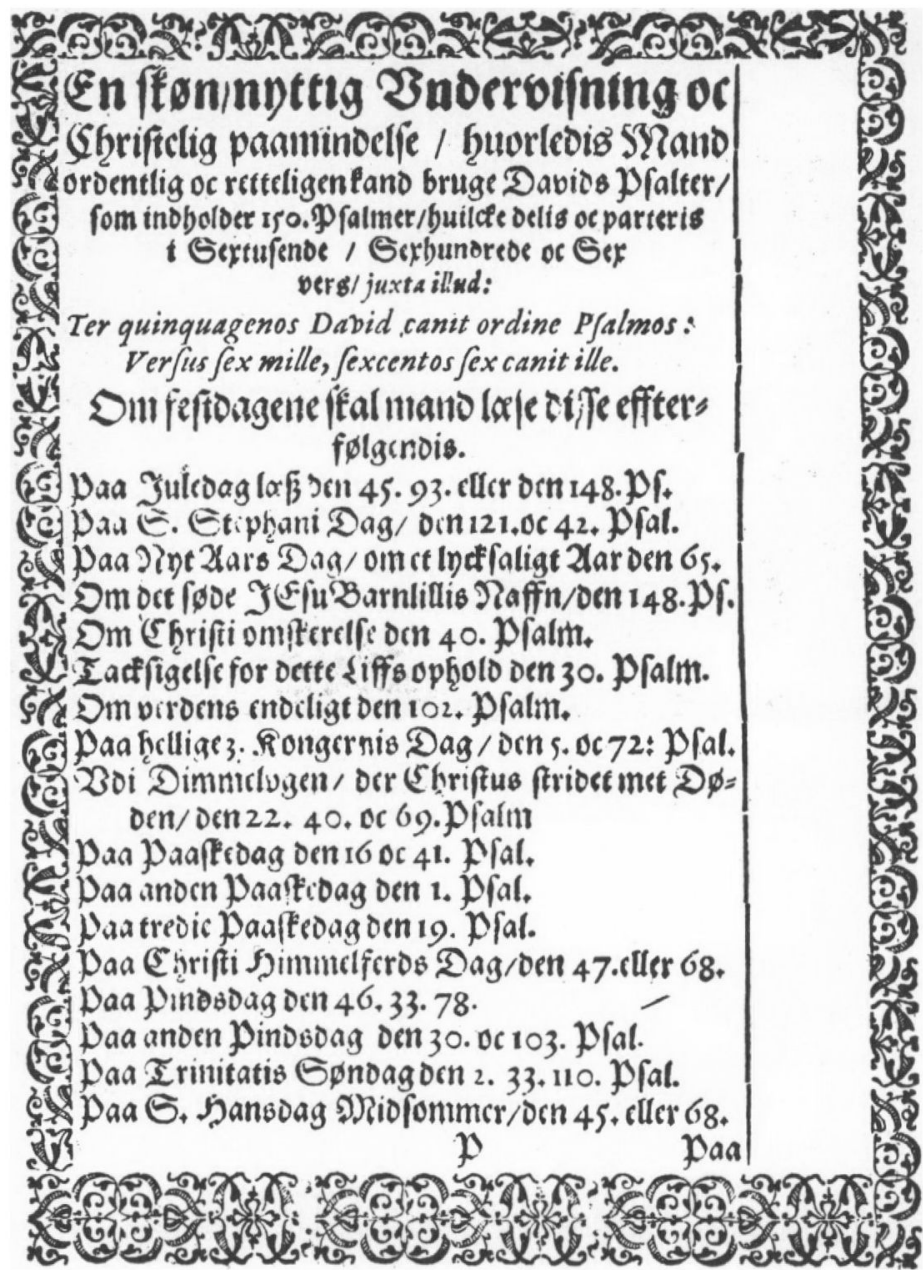

Fig. 3.

Gengivelsen her og pä modstäende side viser de to forste sider af Niels Heldvads undervisning om Davids-Psalmernes brug. Det ses tydeligt, hvordan han både folger og supplerer anvisningerne i sit tyske forlog. Foto: Det Kongelige Bibliotek, Kobenhatn.

Gennemgár vi videre $i$ vor tyske udgaves andet og tredie register de enkelte rubrikker - årets festdage, søndage og aposteldage samt de forskellige tilfælde i præsters, ovrighedspersoners og andre kristnes liv - ser vi, at Niels Heldvad afviger fra sit tyske 


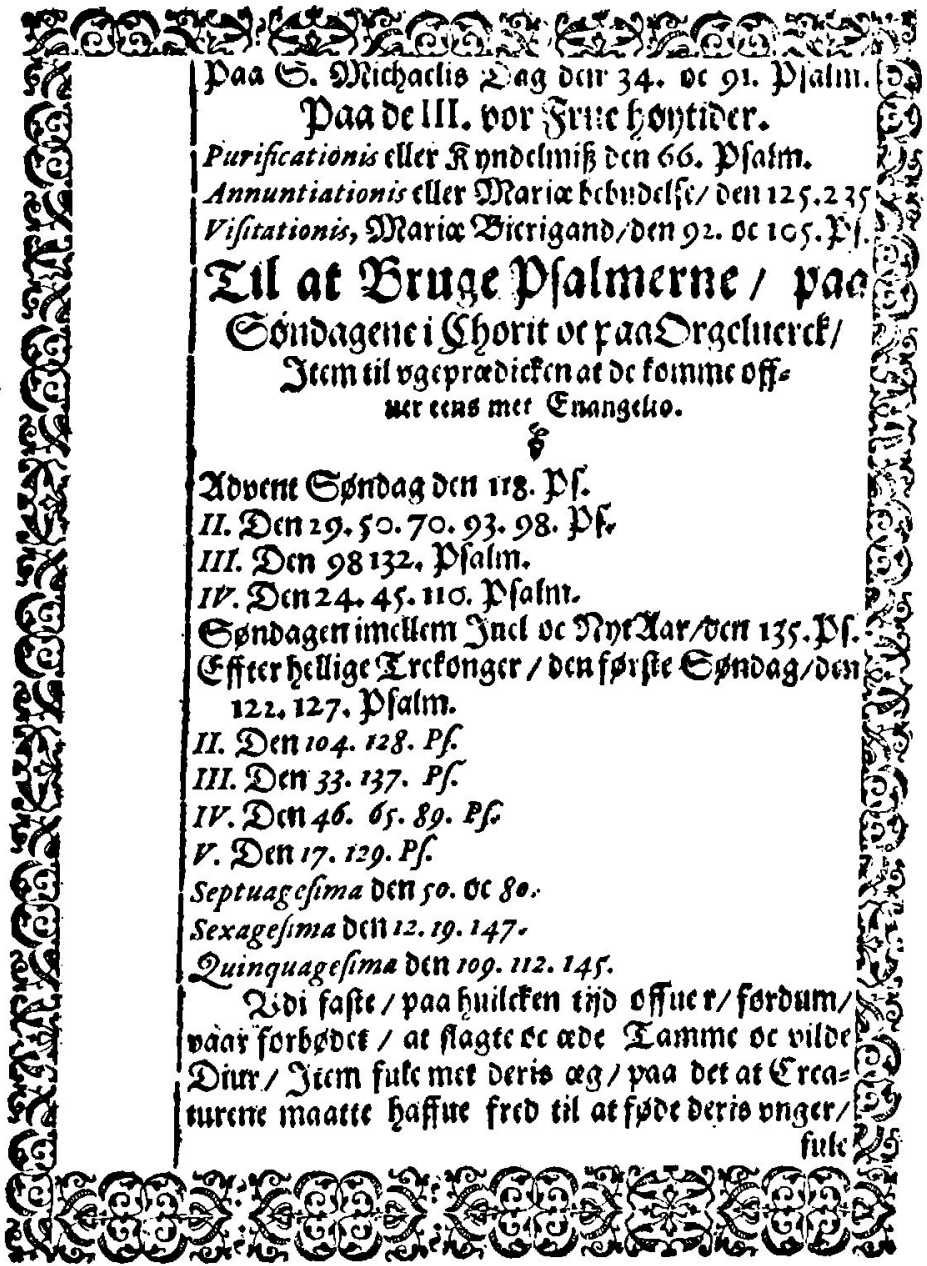

Fig. $3 a$.

forlæg kun i 4 tilfælde ved udeladelse af nogle af dettes rubrik$\operatorname{ker}^{24}$ og kun i 7 tilfælde ved tilføjelse af egne nye rubrikker. ${ }^{25}$ Herudover har han - som det er typisk for ham - givet sit forlæg en ny sprogdragt og enkelte typisk Heldvad'ske, historiske tilføjelser - f. ex. denne, at i fastetiden »var forbødet at slagte og æde tamme og vilde dyr, item fugle med deres æg, på det at kreaturene måtte have fred til at føde deres unger - - til 
menneskens føde og bedste (Pvf). Helt i overensstemmelse med sine personlige erfaringer har han under prasters bønner ogsâ gengivet sit forlægs knappe udtryk "So verfolget werden " (P8) med disse langt stærkere ord: »Præster, som lide forfølgelse af tyranner, voldsmænd, tingspradere og blodhunde " (P3) — vi øjner bag disse gloser hele rækken af de mænd ved det gottorpske hof og i hjemegnen, som var med til at fordrive ham fra hans præsteembede. $^{28}$

Således har Niels Heldvad i udpræget grad givet sit forlæg sit eget personlige præg. Det er ikke forblevet ved den mekaniske afskrivning, da den tyske Psalterudgave lå på hans skrivepult; men hans pen, der alle dage skrev på sin egen originale måde, har også her givet hans forlæg det typiske Niels Heldvad-arbejdes dragt. $^{27}$

Men hvordan forholder det sig med de psalmer, som han i de enkelte tilfælde anfører $\mathrm{i}$ sin „Vndervisning «? $\mathrm{Er}$ de helt de samme som dem, hans kilde anfører? Nej, her konstaterer vi en hel del afvigelser. Nogle lader sig naturligst forklare som trykfejl. ${ }^{28}$ Andre vidner om, at Niels Heldvad har villet supplere sin kildes forslag, som han vel har fundet for kortfattede." Atter andre afvigelser viser et helt selvstændigt valg, hvilket vidner om, at han også i nogen grad har stillet sig kritisk til sit forlæg. ${ }^{80}$ Men der er også talrige exempler på, at han slavisk følger sin kildes psalmevalg. ${ }^{31} \mathrm{Og}$ trods alle forskelle mellem psalmevalget hos Niels Heldvad og i det tyske Psalters registre mả vi sige, at det er disse sidste, der er den røde tråd gennem hele hans $\$$ Vndervisning " om Davids psalmers brug.

Vil vi til slut samle resultatet af denne lille undersøgelse, da bliver det for det første dette, at vi kan korrigere Gregersens ovennævnte hypotese derhen, at Niels Heldvad meget vel kan have forestået kirkelige tjenester i Svendborg og det gamle Holmekloster; men det kan udfra hans „Vndervisning" om Davidspsalmernes brug ikke sluttes sikkert, at disse hans kirketjenester har været egentlige tidebønner $\mathrm{i}$ traditionel betydning: Tidebønner på hverdagene ugen igennem.

For det andet får vi her en interessant lejlighed til sammen med Niels Heldvad at træde hen til hans skrivepult og kigge ham over skulderen, mens han er i gang med udarbejdelsen af et af sine 
skrifter. Der gives os her et sjældent og nært indblik i en for længst afdød skribents litterære arbejdsmåde - århundrederne glider til side; og vi føler os sammen med ham under hans arbejde med pennen. Og alene dette er til et dybere kendskab til en af vor landsdels mærkeligste sønner ikke uden værdi.

Endeligt for det tredie synes vi her at have genfundet et hidtil ukendt slesvigsk bogtryk og har således en bekræftelse mere på det af flere forskere nævnte faktum, at vi endnu befinder os langt fra et nogenlunde dækkende kendskab til, hvad der egentligt er blevet trykt igennem tiderne på slesvigsk grund. ${ }^{33} \mathrm{Og}$ vi har endvidere her i påvisningen af kilden til Niels Heldvads "Vndervisning " om Davidspsalmernes brug et exempel pâ, hvordan et slesvigsk bogtryk har øvet sin indflydelse på en i liøbenhavn udgivet bog. Trods den isolering overfor kongeriget, som hertugdømmet Slesvig gennem adskillige århundreder har måttet finde sig $\mathrm{i}, \mathrm{og}$ trods den ligegyldighed, man i det danske monarkis hovedstad ofte udviste overfor det åndsliv, der trivedes her i hertugdømmet, har dette sidste dog også ydet sine bidrag til kongerigets åndsliv. Dette er slet ikke noget nyt. Men Niels Heldvads "Vndervisning" om Psalterets brug og påvisningen af dens litterære kilde er et exempel mere til bekræeftelse herpå.

\section{NOTER}

1. H. V. Gregersen: Niels Heldvad, 1957, s. 107 ff. og 119.

2. Se fortegnelsen over Niels Heldvads forfatterskab hos Gregersen s. 179 ff. og i H. Ehrencron-Müller: Forfatterlexikon omfattende Danmark, Norge og Island indtil 1814, III, s. $494 \mathrm{ff}$.

3. Skriftet er omtalt og dets titelblad gengivet hos Gregersen s. $156 \mathrm{f}$. Se også H. F. Rordam: Historiske Samlinger og Studier IV, 1902, s. $403 \mathrm{ff}$.

4. De var sønner af præsten i Udbjerg Andreas Gonsager. Se om denne Arends I, s. 286.

5. TRIFOLIUM Theologicum, bl. Bv.

6. Se om dette skrift Gregersen s. 166 ff. og Rordam IV, s. 415 ff.

7. Bl. (b) 4 .

8. Se omtalen og titelbladets gengivelse hos Gregersen s. 121 ff. og Rordam IV, s. 377 ff.

9. I alt fald er fortalen underskrevet på Korsets ophøjelses dag, 14. sept., 1616 "ex umbraculo peregrinationis meæ" (bI. B 2 v) - ifra mit rejsetelt $\propto$.

10. Læg mærke til, at Niels Heldvad bruger det gamle katolske udtryk: at lase en psalme eller bon, ligesom man laste en messe. Jfr. at 
udtrykket er selvfolgeligt endnu for H. C. Andersen, der f. ex. i eventyret Reisekammeraten lader hovedpersonen Johannes, før han drager ud i verden, lase et Fadervor ved sine forældres grav, ligesom han senere også laser sin aftenbøn. Se H. C. Andersen: Samlede Eventyr, udgivet af H. Fonsmark I, 1958, s. 68 og 70.

11. Gregersen s. 121 og 123. Gregersen skriver sidst anforte sted: sMon det skulle dreje sig om et forlæg for de forskellige ugedages tidebønner, som han kan have benyttet under sine ophold i Svendborg kloster og det gamle Holmekloster? .

12. Texterne herom er lettest tilgængelige i H. F. Rordam: Danske Kirkelove I, 1883, s. 52 ff., 94, 122 og 133 og i Die Schleswig-Holsteinische Kirchenordnung von 1542, herausgegeben von Ernst Michelsen II, 1920, s. 19 ff., 74 f., 116 og 155 ff. Endnu udgaven 1640 af kirkeordinansen medtager Bugenhagens s Ordinatio Ceremoniarum pro Canonicis \& Monasterijs (Bl. Off.), hvori vi finder anvisninger for tidebønnerne (Bl. Q6 ff.), ligesom også 2. udgave al' -Christlyke Kercken Ordeninge/ De yn den Fïrstendömen/Schlesswig/ Holsten etc. schal geholden werdenn \&, Slesvig 1601, bringer den samme Ordeninge der Ceremonien/ vor Domheren vnde Clöster (Bl. Rv ff. med tidebønneanvisningerne bl. V3 ff.). Og så sent som 1665 finder vi $i$ •Das Schlesswigische und Holsteinische Kirchen Buch (trykt i Slesvig samme år) en lang række bibelske psalmer og middelalderlige hymner - endda alle på latin - til brug ved dagens 7 . tidebøn, vesperen (I, s. 126 ff.). Om tidebønnens udvikling under og efter reformationen i Danmark se iøvrigt S. Widding: Dansk Messe, Tide- og Psalmesang 1528-1573 I, 1933, s. $166 \mathrm{ff}$.

13. Widding I, s. $177 \mathrm{ff}$. og Sv. Borregaard: Danmarks og Norges kirkeritual af 1685,1953 , s. $118 \mathrm{ff}$.

14. Endnu $i$ året $\mathbf{1 7 0 0}$ holdtes $\mathrm{i}$ gråbrodreklosterets kirke i Svendborg en ugentlig onsdagsgudstjeneste. Se Kirkehist Saml 4. r. VI, s. 790.

15. Widding $\mathrm{I}, \mathrm{s} .161 \mathrm{ff}$.

16. Om de allerede $\mathrm{i}$ kirkeordinansen omtalte hverdagsgudstjenester, især på onsdagene og fredagene, se Widding $I$, s. $214 \mathrm{f}$.

17. Se f. ex. i $>$ HISTORIARUM SACRARUM ENCOLPODION afsnittet om de gode gamle kirkeceremonier (BI. $255 \mathrm{ff}$.), der er en let omarbejdet, sine steder ordret afskrift af store partier af Niels Heldvads eget skrift fra 1597 ELEVSINIA SACRA

18. Et godt exempel herpå er Niels Heldvads opbyggelsesskrift $\gg \mathrm{Al}^{-}$ mamentarium Davidicum. Det er: Kong Davids Tyghuss - 1630. Se referat af dets meget blandede indhold hos Rordam IV, s. $388 \mathrm{ff}$. samt Erik Dals pảvisning af den franske kilde til Niels Heldvads i skriftet optagne månedsdigt i: Niels Heldvad: En smuk ihukommelse om menneskets alder efter de 12 måneder i iret afdelt. Udgivet af Erik Dal, Odense 1960, s. 45 ff. Et andet vidnesbyrd om samme litterære fremgangsmåde er de talrige litteraturhenvisninger, hvormed Niels Heldvad har forsynet sin RIARUM SACRARUM ENCOLPODION *, især værkets 4. bog - MARTYROLOGIA SANCTORUM. En forklaring paa de Aarlige Calender/ som mand bruger i Christendommens. 
19. Se om ham A. Sach: Geschichte der Stadt Schleswig nach urkundlichen Quellen, 1875, s. 218, n. 2.

20. Bogen, som er i lille oktavformat og har haft c. 360 sider, er efter tahet af sit oprindelige bind blevet nodforftigt forsynet med et groft påsyet kardusomslag. Den er fundet hos gårdejer Karl Svennesen på Barsø. Hverken Bibliotheca Danica I, sp. 28 f. eller dette værks supplementbind kender nogen anden tysk, på slesvigsk grund trykt Psalterudgave end Nicolaus Wegeners fra 1582, hvorfor vi her sikkert stâr overfor et hidtil ukendt - i det mindste uregistreret - slesvigsk bogtryk.

21. F. ex. i summariet til ps. 1: "ISt eine Vermahnung, dass wir uns zu Gottes Wort halten, und für falscher Lehre hüten sollen - (S. 7), hvor Wegeners udgave har folgende: "Ist ein Vermmung/ das wir vns zu Gottes Wort halten/ vnd fur falscher I.ehr hüten sollen - - - Fremhævelserne er foretaget her.

22. Vor udgave har her f. ex. et lidt andet psalmeudvalg, der dels skyldes trykfejl, dels at nogle flere psalmer anfores. Desuden har den

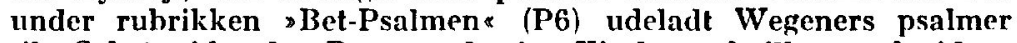
til "Gebet wider den Bapst vnd seine Kirchen *, hvilket også vidner om et senere udgivelsesår.

23. Det fjerde register (P10 ff.), som her ikke skal beskæftige os, er en fortegnelse over alle psalmerne og deres antifoner, wie solche von den Kindern in Teutschen Schulen - - - können gelesen, und darauf auswendig gelernet werden a.

24. Det drejer sig her om det tyske Psalters »Dancksagung für Rettung aus der Tyrannen Hand " og $>$ Um Erhaltung der Kirchen Gottes « (begge P8), om So kriegen muss (P8 v) og om dets , Wer Kindes-Kinder hat * (P9).

25. Efter nytårsdag tilfajer han således $\gg \mathrm{Om}$ det søde Jesu Barnlilles navn ", Om Kristi omskærelse , » Taksigelse for dette livs ophold * og Om verdens endeligt «. Efter påskedag næwner han også 2. og 3. påskedag (P). Imellem 4. søndag i advent og 1 . sondag efter Hellig tre Konger indfojer han sondag $i$ juleugen (Pv). Til fortegnelsen over præsternes bønner fajer han en bon for ssimple og enfoldige præstemænde (P3v), ligesom han supplerer ovrighedens bonner med ps. 52, $70 \mathrm{og} 109$ for tyranner, dersom de onsker at vide, shvad deres undersåtter bede og onske dennem* (P4).

26. Bemærk også hans ord om de unge fyrster: "At de intet befatte sig med kirken eller kirkegods, ej heller forhindre gudstjeneste (P3v)! Det er hans slægts hele præsteharme over de fyrstelige overgreb overfor kirken, som både reformationen $i$ vor landsdel og den senere calvinisme ved hoffet på Gottorp medforle, der her kommer til orde. Se Gregersen s. 11 og $61 \mathrm{ff}$.

27. At han dog også kan blive tro ved sit forlæg, viser $f$. ex. det tyske Psalters udtryk *Wer Kinder und Freunde zur Erde bestattet (P9v), der hos Niels Heldvad er blevet til folgende: \$Naar du - følger dine børn og gode venner til deres lejersted. (Q).

28. F. ex. når han til brug på Sct. Stefans dag anforer ps. 42 og 121 (P), mens forlæget har ps. 41 og 121 - her synes forlægets valg også at passe bedre til dagen end Niels Heldvads. Eller når han pă 
Hellig tre Kongers dag nævner ps. 5 og 72 (P) mod forlægets ps. 5 og 27 (P6v) eller på 2. søndng $\mathrm{i}$ advent bl. a. ps. 93 (Pv) mod forlægets ps. $63(\mathrm{P} 6 \mathrm{v})$ eller på 3. søndag efter påske ps. 12 og 45 (P2) mod sin kildes ps. 12 og 46 (P7).

29. Se blot 3. søndag efter trinitatis: Ps. 32, 51 og 95 (P2), til hvilken dag forlæget kun nævner ps. 95 (P7v).

30. Her kan nævnes 5. sondag efter påske, til hvilken Niels Heldvad vælger ps. 1, 104 og 141 (P2), mens det tyske Psalter kun vælger ps. 50 (P7). Eller 21. søndag efter trinitatis: Ps. 27, 42, 48 og 86 (P2v) mod forlægets ps. 86 alene (P7v). Eller $\gg \mathrm{Om}$ fred og godt regimente den 61. psalm. (P3v) mod forlagets Um friedliche Regierung, den 148.a (P8v).

31. Blot folgende exempel: Til brudevielse ps. 127 og 128, efter barnefødsel ps. 103 (begge $\mathrm{P} 4)$ og for altergangen ps. 51 og $130(\mathrm{Qv})$, hvilke alle genfindes til de samme lejligheder $i$ det tyske forlæg (P8v og 9v).

32. Og at han faktisk har gjort dette, i det mindste i Svendborg, er en kendsgerning. Se Gregersen s. 121.

33. Stadigt dukker nu og da ukendte slesvigske tryk op af århundreders glemsel og ubemærkethed. Se sỉledes Hans Magles redegorelse for den genfundne, ellers ukendte plattyske Flensborg-salmebog fra 1641 i SJy MSkr 1959, s. 245 ff. samt H. Hejselbjerg Paulsen: Sonderjydsk Psalmesang 1717-1740, 1961, s. 371. Siore dele af sidstnævnte arbejde bygger iøvrigt på hidtil ukendte, ja, endnu ikke genfundne tryk fra slesvigsk område. $\mathrm{Og}$ selv hỉber jeg i en kom. mende afhandling at kunne gore opmærksom på nogle hidtil ikke bemærkede Iuckandertryk fra Haderslev. 